\section{Validasi Lokasi Perizinan Perkebunan Dalam Pengendalian Pemanfaatan Ruang di Kabupaten Paser}

\section{Toto Ifrianto}

Kepala Bidang Tata Ruang

Dinas Pekerjaan Umum dan Tata Ruang Kabupaten Paser Provinsi Kalimantan Timur

totoifrianto@gmail.com

\section{Pendahuluan}

Budidaya perkebunan kelapa sawit merupakan sektor komoditi andalan Kabupaten Paser, dengan total produksi tahun 2018 mencapai 1.979.831,30 ton untuk luasan $182.723,72$ Ha dan menempati urutan kedua penyumbang PDRB terbesar setelah sektor pertambangan (BPS, 2019).

Walaupun demikian sektor perkebunan masih menyimpan permasalahan yang harus diselesaikan yaitu permasalahan penguasaan dan overlaping batas lokasi/tanah yang ditunjuk oleh pejabat berwenang melalui Izin Lokasi dan/atau Izin Usaha Perkebunan (IUP) yang kerap berujung di pengadilan perdata. Hal ini menjadi preseden buruk bagi pemerintah daerah yang dinilai tidak cermat dan lalai dalam pemberian izin perkebunan.

Permasalahan tersebut di atas disebabkan 1) peta perkembangan yang menggambarkan seluruh izin-izin yang sudah diterbitkan tidak di update dan tidak dilengkapi data atribut; 2) terdapat peta masih konvensional dan belum mengacu pada peta dasar yang telah ditetapkan (RBI); 3) di beberapa izin tidak dilampirkan peta lokasi; 4) kurangnya SDM terampil dalam pemetaan dan analisa geospasial; dan 5) terdapat beberapa perizinan perkebunan yang tidak melalui prosedur yang berlaku.

Sektor perkebunan masih menyimpan
permasalahan mendasar yaitu overlaping
penguasaan lahan dan batas lokasi yang ditunjuk
dalam Izin Lokasi dan Izin Usaha Perkebunan.
Artikel ini fokus membahas validasi lokasi
perizinan perkebunan di Kabupaten Paser
sehingga perkembangan seluruh izin perkebunan
dapat diketahui. Hasil validasi ini juga dapat
digunakan sebagai pertimbangan teknis kepada
pejabat yang berwenang untuk melakukan
perbaikan terhadap izin lokasi dan izin usaha
perkebunan yang bermasalah, pengendalian
pemanfaatan ruang, dan peninjauan kembali
RTRW Kabupaten Paser. Metode yang digunakan
adalah metode analisa deskriptif dan analisa
spasial melalui Sistem Informasi Geografis. Dari
hasil analisa data spasial diketahui bahwa luas
areal perkebunan di Kabupaten Paser dari batas
terluar izin adalah seluas \pm 230.162 Ha dari
penguasaan lahan perkebunan sebelum validasi
seluas \pm 409.506 Ha $(56,20 \%)$
Kata kunci: Izin Lokasi Perkebunan, Izin Usaha
Perkebunan, overlaping, analisis spasial, SIG, pengendalian
pemanfaatan ruang
Diajukan: 11 Juni 2020
Direvisi: 16 Juni 2020 Diterima: 29 September 2020 .
Dipublikasikan online: 26 Oktober 2020

Pada kondisi awal sebagaimana Gambar 1 ditunjukan bahwa dari luas Areal Penggunaan Lain/Kawasan Budidaya Non Kehutanan di Kabupaten Paser seluas $\pm 477.334 \mathrm{Ha}$ dimana lebih dari $80 \%$ lahannya dikuasai oleh izin lokasi perkebunan (lokasi diarsir) dan di beberapa tempat terdapat adanya overlap izin lokasi. Sedangkan pada Gambar 2, lokasi yang di arsir merupakan Izin Usaha Perkebunan di Kabupaten Paser.

Dengan total luas IUP $\pm 280.580 \mathrm{Ha}$ masih terdapat beberapa lokasi perusahaan yang masih saling tumpang tindih.

Permasalahan ini juga berimbas pada pengendalian pemanfaatan ruang dimana sebagian besar lokasi perkebunan terdapat fungsi ruang yang tidak sesuai dengan peruntukannya sehingga menyebabkan investasi di luar sektor perkebunan menjadi terhambat karena blocking area izin perkebunan.

Berkenaan hal-hal tersebut di atas, maka perlu dilakukan validasi lokasi perizinan perkebunan berbasis spasial dengan harapan dapat diketahui perkembangan seluruh izin perkebunan, memberikan pertimbangan teknis kepada pejabat yang berwenang untuk melakukan perbaikan terhadap lokasi Izin Lokasi dan Izin Usaha Perkebunan yang bermasalah, serta sebagai dasar dalam mengendalikan pemanfaatan ruang dan bahan pertimbangan perencanaan tata

Cara mensitasi artikel ini:

Ifrianto, T (2020) Validasi Lokasi Perizinan Perkebunan Dalam Pengendalian Pemanfaatan Ruang. Buletin Profesi Insinyur 3(2) 109-117 


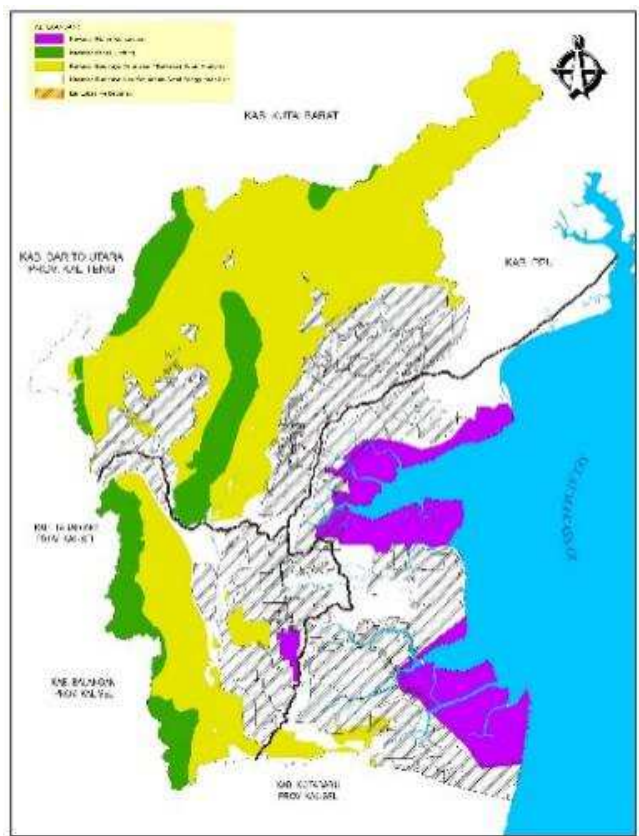

Gambar 1. Perkembangan Izin Lokasi Perkebunan Kabupaten Paser

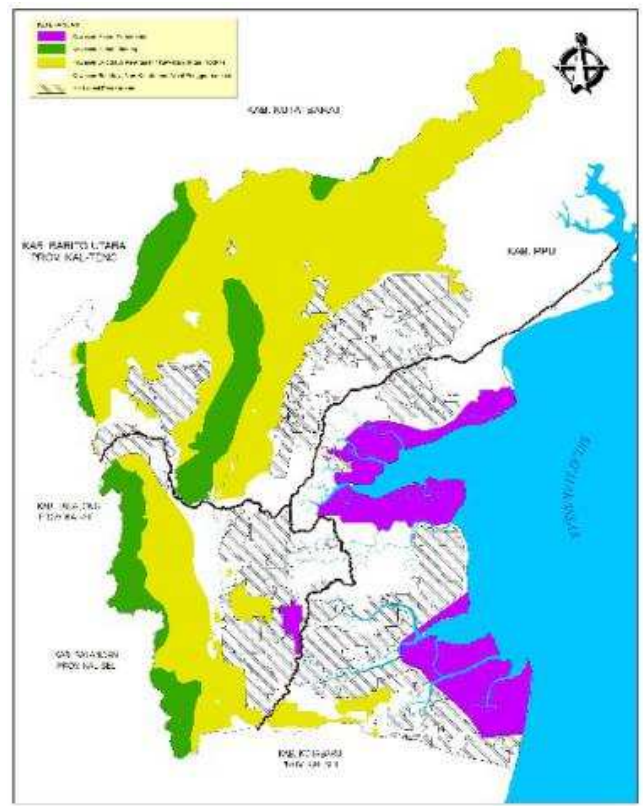

Gambar 2. Perkembangan Izin Usaha

Perkebunan Kabupaten Paser

ruang pada kegiatan Peninjauan Kembali RTRW Kabupaten Paser.

\section{Metode}

Dalam pelaksanaan validasi peta perizinan perkebunan, metode yang dilakukan dengan menggunakan analisa deskriptif dan analisa spasial melalui Sistem Informasi Geografis (SIG).

Sebagai sebuah metode, analisis spasial berusaha untuk membantu perencana dalam menganalisis kondisi permasalahan berdasarkan data dari wilayah yang menjadi sasaran. Dan konsep-konsep yang paling mendasari sebuah analisis spasial adalah jarak, arah, dan hubungan. Kombinasi dari ketiganya mengenai suatu wilayah akan bervariasi sehingga membentuk perbedaan yang signifikan yang membedakan satu lokasi dengan yang lainnya. Dan ketiga hal tersebut merupakan hal yang selalu ada dalam sebuah analisis spasial dengan tahapantahapan tertentu tergantung dari sudut pandang perencana dalam memandang sebuah permasalahan analisis spasial (Cholid, 2009:5).

Pada pengolahan data SIG, analis spasial dapat digunakan untuk memberikan solusi-solusi atas permasalahan keruangan. Manfaat dari analisis spasial tergantung dari fungsi yang dilakukan, antara lain : 1) membuat, memilih, memetakan, dan menganalisis data raster berbasis sel; 2) melaksanakan analisis data vektor/raster yang terintegrasi, 3) mendapatkan informasi baru dari data yang sudah ada. 4) memilih informasi dari beberapa layer data, dan 5) mengintegrasikan sumber data raster dengan data vector (Pusat Infrastruktur Data Spasial, 2017).

Dalam proses validasi data perizinan perkebunan dilakukan dengan tahapan, antara lain :

1) Persiapan, meliputi : rapat koordinasi untuk membahas penyusunan rencana anggaran, penetapan schedule serta personil yang terlibat.

2) Pelaksanaan Validasi Data Informasi Geospasial Tematik (IGT) meliputi : kompilasi data, integrasi, serta sinkronisasi seperti terlihat pada Gambar 3 (Nurwadjedi, 2016).

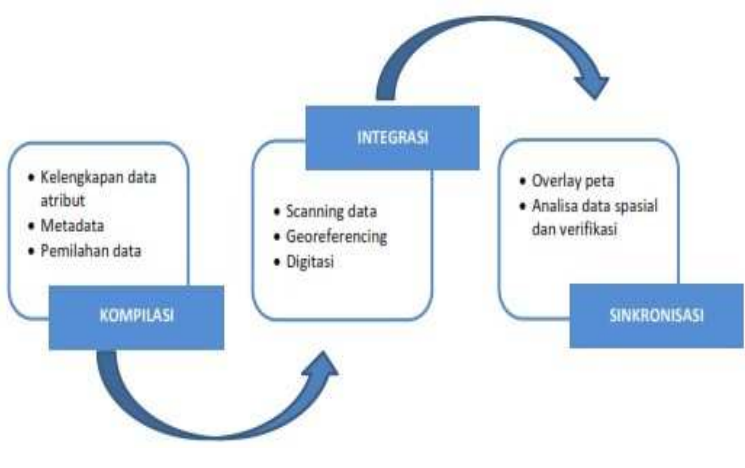

Gambar 3. Rangkaian Proses Validasi IGT

\section{Kompilasi Data}

Kompilasi data merupakan kegiatan pengumpulan data untuk diseleksi, ditabulasi, dan dikelompokan secara sistematis sesuai dengan kebutuhan data yang diperlukan (definisiparaahli, 2016).

Pengumpulan data ini merupakan faktor penting demi keberhasilan penelitian dalam penarikan kesimpulan. Hal ini terkait dengan cara mengumpulkan data, sumber data, dan alat yang digunakan (Sariwang, 2016). 
Mengingat pentingnya akurasi data dalam validasi lokasi perizinan perkebunan, maka data dikumpulkan secara historical berupa dokumen SK dan lampiran peta baik Izin Lokasi Perkebunan maupun Izin Usaha Perkebunan sejak diterbitkan sampai dengan perubahan dan/atau perpanjangan terakhir. Kemudian dokumen yang dikumpulkan/didokumentasikan menjadi suatu metadata dalam suatu tabel tabulasi yang berisikan atribut sebagaimana terlihat pada Tabel 1.

\section{Integrasi Data}

\section{Scanning Data}

Sebagai langkah awal dalam memproduksi data spasial dalam format digital, peta-peta analog (berupa print out atau cetakan) dilakukan scan menjadi image scanning dalam format yang dikenali oleh ArcGIS seperti format jpg, tif, bmp, gif, dan bmg. Hasil scan akan menghasilkan data raster yang akan di convert menjadi data vektor. Untuk menjaga kerusakan dan hilangnya dokumen, scanning dilakukan pula pada dokumen SK Izin Lokasi dan Izin Usaha Perkebunan menjadi suatu data base.

\section{Georeferencing}

Data raster yang diperoleh dari hasil scanning peta belum berisi informasi yang menunjukan referensi spasial, baik yang tersimpan di dalam file atau yang disimpan sebagai sebuah file yang terpisah. Sehingga untuk menggunakan beberapa data raster secara bersama dengan data spasial lain yang sudah ada diperlukan proses georeferencing, yaitu proses pemberian referensi geografi atau memberikan suatu sistem koordinat dari objek berupa raster atau image yang belum mempunyai acuan sistem koordinat ke dalam sistem koordinat dan proyeksi tertentu (Balai Diklat Kehutanan, 2011).

Penyamaan sistem koordinat disesuaikan dengan koordinat yang tercantum dalam peta hasil scanning seperti koordinat geografis, UTM, TM, dll.

\section{Digitasi}

Digitasi merupakan suatu proses mengkonversi data analog menjadi data digital dimana dapat ditambahkan atribut yang berisikan informasi dari objek yang dimaksud. Proses digitasi akan menghasilkan suatu file dengan format shapefile (.shp) yaitu format data vektor yang digunakan untuk menyimpan lokasi, bentuk, dan atribut dari fitur geografis. Format data shp disimpan dalam satu set file terkait dan berisi dalam satu kelas fitur (Prasetyo, 2014).

\section{Tabel 1. Format Data Izin Lokasi Perkebunan dan Izin Usaha Perkebunan}

\begin{tabular}{|c|c|c|c|c|c|c|c|c|c|c|c|c|c|c|c|}
\hline \multirow[b]{2}{*}{ No } & \multirow[b]{2}{*}{$\begin{array}{c}\text { Nama } \\
\text { Perusahaan }\end{array}$} & \multirow[b]{2}{*}{$\begin{array}{l}\text { Group } \\
\text { usaha }\end{array}$} & \multirow[b]{2}{*}{$\begin{array}{l}\text { Penerbit } \\
\text { Izin }\end{array}$} & \multirow[b]{2}{*}{$\begin{array}{l}\text { No, } \\
\text { SK }\end{array}$} & \multirow[b]{2}{*}{$\begin{array}{c}\text { Tanggal } \\
\text { SK }\end{array}$} & \multirow[b]{2}{*}{$\begin{array}{l}\text { Luas } \\
\text { menurut } \\
\text { SK }(\mathrm{Ha})\end{array}$} & \multirow[b]{2}{*}{$\begin{array}{c}\text { Masa } \\
\text { Belaku } \\
\text { Izin }\end{array}$} & \multirow[b]{2}{*}{ Desa } & \multirow[b]{2}{*}{ Kecamatan } & \multirow[b]{2}{*}{ Kabupaten } & \multirow[b]{2}{*}{ Status } & \multicolumn{4}{|c|}{ Checklis Ketersediaan } \\
\hline & & & & & & & & & & & & SK & $\begin{array}{c}\text { Peta } \\
\text { lampiran } \\
\text { SK }\end{array}$ & $\begin{array}{c}\text { Data } \\
\text { Spasial }\end{array}$ & $\begin{array}{l}\text { Atribut } \\
\text { Spasial }\end{array}$ \\
\hline 1. & PT. A & & & & & & & & & & & & & & \\
\hline 2. & PT. B & & & & & & & & & & & & & & \\
\hline 3. & dst .............. & & & & & & & & & & & & & & \\
\hline
\end{tabular}

Pada kegiatan validasi ini, digitasi peta analog hasil scan yang telah di georeferencing dilakukan dengan menggunakan komputer (Digitasi on Screen) dimana komputer telah dilengkapi dengan software pemetaan seperti ArcGIS, ArcView atau yang lainnya. Dan peta setiap izin perkebunan (Izin Lokasi/IUP) yang didigitasi adalah data izin terakhir yang kemudian diberi atribut sebagaimana tabel format Tabel 1.

\section{Sinkronisasi Data}

\section{Overlay Peta}

Overlay adalah prosedur penting dalam analisis spasial melalui Sistem Informasi Geografis (SIG). Overlay peta merupakan suatu proses penampalan/ penggabungan 2 (dua) atau lebih layer baik format vector maupun raster beserta atribut-atributnya menjadi suatu peta baru, sebagaimana ilustrasi dalam Gambar 4.

Overlay peta juga menjadi suatu alat untuk mengetahui adanya suatu permasalahan dalam suatu peta tematik seperti tumpang tindih penggunaan lahan, celah/gaps dari kegiatan yang berbatasan, dan cakupan data dalam fitur.

Dalam proses ini, layer-layer shapefile perkebunan di-overlay-kan dengan peta dasar RBI dan peta tematik lainnya seperti Peta Kawasan Hutan, Peta RTRW, dan Peta IUPHHK.

\section{Analisa Data Spasial dan Verifikasi}

Dari hasil penampalan peta/layer dari masing-masing lokasi perkebunan dilakukan analisis spasial secara mendetail dengan menggunakan fitur topologi pada SIG.

Topologi yaitu pendefinisian secara matematis yang menerangkan hubungan relatif antara objek satu dengan objek yang lain. Dalam GIS topologi didefinisikan oleh user sesuai dengan karateristik data seperti line, polygon maupun point/titik (Sudomo, 2015). Setiap karateristik data tertentu mempunyai rule/aturan tertentu. Untuk proses validasi IGT perkebunan ini, objek polygon shapefile perkebunan ditentukan aturan/rule sebagai berikut :

1) antar polygon perusahaan perkebunan tidak boleh saling bertampalan/overlap (must not overlap);

2) antar polygon perusahaan perkebunan tidak boleh ada celah/gap (must not gaps);

3) polygon perusahaan perkebunan harus berada dalam wilayah kabupaten yang bersangkutan sesuai kewenangan (must be covered by features). 


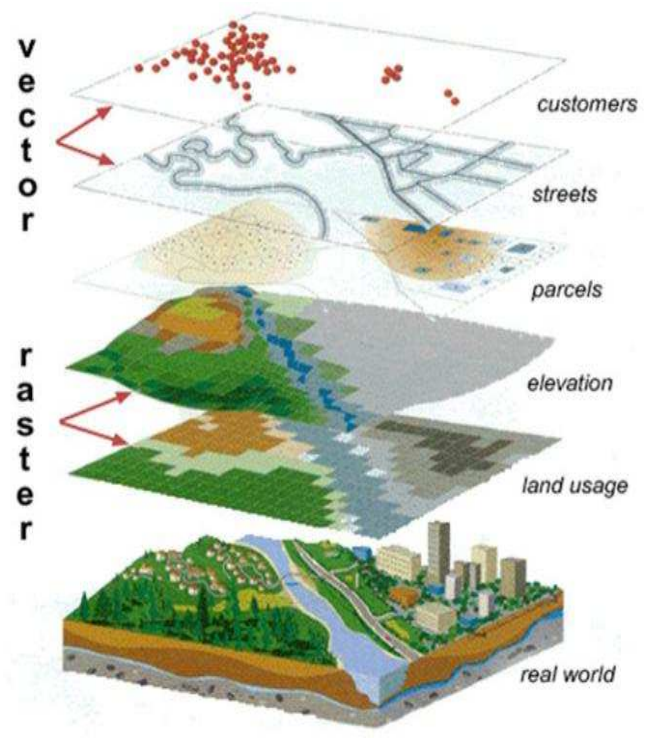

Gambar 4. Teknik Overlay Dalam SIG

Berdasarkan hasil overlay maupun topologi, selanjutnya terhadap seluruh permasalahan lahan perkebunan dilakukan inventarisasi permasalahan untuk ditindaklanjuti sesuai kapasitas dan kewenangan dalam melakukan perbaikan ataupun revisi.

\section{Hasil Kerja}

\section{Rapat Koordinasi}

Dalam menyampaikan latar belakang, maksud dan tujuan kegiatan validasi IGT perkebunan di Kabupaten Paser, Dinas Pekerjaan Umum dan Tata Ruang Kabupaten Paser telah melakukan rapat koordinasi bersama Sekda Kabupaten Paser, Asisten Perekonomian dan Pembangunan, Bappeda, Dinas Penanaman Modal dan Pelayanan Terpadu Satu Pintu, Dinas Pertanian dan Perkebunan, Dinas Perumahan, Kawasan Permukiman dan Pertanahan, Dinas Lingkungan Hidup, dan Kantor Pertanahan Kabupaten Paser pada tanggal 16 Juli 2019.

Pelaksanaan kegiatan validasi dilakukan selama 6 bulan sejak Juli - Desember 2019 dengan pembebanan anggaran dari APBD Kabupaten Paser Tahun 2019.

\section{Kompilasi Data}

Berdasarkan hasil pengumpulan data dari beberapa Organisasi Perangkat Daerah (OPD) terkait yang memproses penerbitan Izin Lokasi Perkebunan dan Izin Usaha Perkebunan diperoleh data sebagai berikut :

1) Izin Lokasi Perkebunan diperoleh 124 arsip SK beserta peta lampirannya berupa izin lokasi awal dan perubahan/perpanjangan (historical) untuk 66 perusahaan perkebunan.

2) Masih terdapat kekurangan 2 SK dan peta lampiran izin Lokasi Perkebunan dimana dinas terkait kabupaten maupun pihak perusahaan tidak mempunyai arsip SK Izin Lokasi beserta lampiran peta dimaksud karena telah peralihan manajemen (take over). Hal ini dikarenakan izin lokasi tersebut merupakan izin lokasi yang saat itu diterbitkan oleh BPN Provinsi dan/atau Gubernur KDH Tingkat I Kalimantan Timur. Dengan demikian data spasial menggunakan data terakhir yaitu peta HGU.

3) Izin Usaha Perkebunan diperoleh 60 arsip SK Izin Usaha Perkebunan berupa izin lokasi awal dan perubahan/perpanjangan (historical) untuk 53 perusahaan perkebunan.

4) Dari 53 IUP tersebut di atas terdapat 14 SK IUP yang diterbitkan Bupati Paser saat itu hanya berupa SK dan tidak dilampiri peta lokasi. Untuk melengkapi data spasial maka lokasi IUP mengacu pada peta lampiran Izin Lokasi perusahaan yang bersangkutan dengan diberi keterangan dalam attribute spasial.

\section{Analisa Data Spasial}

Dari hasil digitasi on screen terhadap seluruh perizinan perkebunan yang kemudian di-overlay kan dengan peta dasar (RBI) dan peta tematik antara lain Peta Bidang Tanah sebagai lampiran Hak Guna Usaha (HGU) maupun yang dalam tahap proses HGU (pengukuran kadastral), Peta Kawasan Hutan, Peta RTRW, dan Peta IUPHHK ditemukan bahwa seluruh perizinan perkebunan baik Izin Lokasi Perkebunan maupun Izin Usaha Perkebunan terdapat permasalahan baik batas lahan perkebunan maupun fungsi peruntukan lahan. Rincian permasalahan tersebut diinventarisasi dengan rincian sebagaimana terlihat dalam Tabel 2.

Berdasarkan Tabel 2 di atas, dari jumlah izin perkebunan yang diterbitkan dibandingkan permasalahan batas lahan perkebunan yang ada nampak bahwa masing-masing perusahaan perkebunan mempunyai satu atau lebih dari satu permasalahan. Hal ini menunjukkan pemberian izin perkebunan di Kabupaten Paser kurang memperhatikan pentingnya batas terluar suatu lokasi perkebunan yang seharusnya menjadi hal paling mendasar dalam suatu pemanfaatan ruang.

Untuk menindaklanjuti permasalahan lahan perkebunan tersebut, harus dilakukan koreksi, verifikasi, sinkronisasi dan penyelarasan data Informasi Geospasial Tematik, dengan mempertimbangkan halhal sebagai berikut:

1) Undang-Undang Nomor 4 Tahun 2011 tentang Informasi Geospasial, Pasal 19 menyatakan bahwa Informasi Geospasial Tematik (IGT) wajib mengacu pada Informasi Geospasial Dasar (IGD). IGD dimaksud merupakan peta dasar yang terdiri atas : a) garis pantai; b) hisoprafi; c) perairan; d) nama rupabumi; dan e) batas wilayah.

Berkenaan hal tersebut maka dalam analisa spasial IGT perkebunan setiap batas lokasi perkebunan yang berbatasan dengan bentang alam seperti 
sungai dan pantai harus dikoreksi dengan mengacu pada Peta Rupa Bumi sebagai peta dasar.

Tabel 2. Inventarisasi Permasalahan Izin Perkebunan

\begin{tabular}{|c|c|c|}
\hline No & Permasalahan & $\begin{array}{c}\text { Jumlah } \\
\text { Perusahaan }\end{array}$ \\
\hline 1 & $\begin{array}{l}\text { Izin Lokasi berakhir, tidak ada } \\
\text { perpanjangan, tidak ada IUP, tidak ada } \\
\text { kegiatan dan belum kadastral }\end{array}$ & 9 \\
\hline 2 & 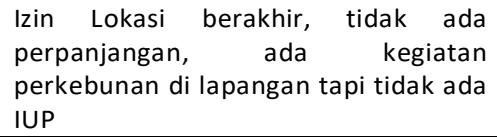 & 2 \\
\hline 3 & $\begin{array}{l}\text { Overlap Ilok dengan Ilok perusahaan } \\
\text { yang sama, luas berbada }\end{array}$ & 13 \\
\hline 4 & $\begin{array}{l}\text { Overlap Ilok dengan Ilok perusahaan } \\
\text { yang lain }\end{array}$ & 52 \\
\hline 5 & Ilok berada dalam kawasan hutan & 19 \\
\hline 6 & $\begin{array}{l}\text { llok berada diluar kawasan hutan } \\
\text { namun tidak sesuai peruntukan } \\
\text { perkebunan pada pola ruang RTRW }\end{array}$ & 61 \\
\hline 7 & Ilok masih dibebani IUPHHK & 3 \\
\hline 8 & $\begin{array}{l}\text { Overlap IUP dengan IUP perusahaan } \\
\text { lainnya }\end{array}$ & 22 \\
\hline 9 & IUP berada dalam kawasan hutan & 10 \\
\hline 10 & $\begin{array}{l}\text { IUP berada diluar kawasan hutan } \\
\text { namun sebagian atau seluruh areal } \\
\text { tidak sesuai peruntukan perkebunan } \\
\text { pada pola ruang RTRW }\end{array}$ & 50 \\
\hline 11 & IUP masih dibebani IUPHHK & 2 \\
\hline 12 & $\begin{array}{l}\text { Overlap antara IUP dengan } \mathrm{HGU} \\
\text { perusahaan lain }\end{array}$ & 8 \\
\hline 14 & Lokasi IUP diluar izin lokasinya sendiri & 2 \\
\hline 15 & $\begin{array}{l}\text { Pergeseran hasil pengukuran kadastral } \\
\text { dengan IUP (lokasi sama) }\end{array}$ & 1 \\
\hline 16 & SK IUP dicabut & 4 \\
\hline 17 & $\begin{array}{l}\text { Tidak ada peta lampiran IUP dimana } \\
\text { luas IUP dan Izin Lokasi berbeda }\end{array}$ & 2 \\
\hline 18 & Lokasi IUP berada diluar HGU/Ilok & 2 \\
\hline 19 & Gap izin lokasi perkebunan & 23 \\
\hline 20 & $\begin{array}{l}\text { Fitur Izin Lokasi Perkebunan di luar } \\
\text { batas administrasi kabupaten }\end{array}$ & 13 \\
\hline 21 & Gap izin usaha perkebunan & 17 \\
\hline 22 & $\begin{array}{l}\text { Fitur Izin Usaha Perkebunan di luar } \\
\text { batas administrasi kabupaten }\end{array}$ & 13 \\
\hline
\end{tabular}

2) Peraturan Menteri Negara Agraria/Kepala BPN Nomor 2 Tahun 1999, yang telah diubah beberapa kali terakhir dengan Peraturan Menteri Agraria dan Tata Ruang/Kepala BPN Nomor 14 Tahun 2018 tentang Izin Lokasi, pada Pasal 4 dinyatakan bahwa objek izin lokasi merupakan tanah yang menurut RTRW diperuntukan bagi penggunaan yang sesuai dengan rencana kegiatan usaha, dan pada Pasal 20 dijelaskan bahwa Izin Lokasi diberikan untuk jangka waktu 3 tahun dan perolehan tanah oleh pemegang izin lokasi harus diselesaikan dalam jangka waktu izin lokasi dan apabila dalam jangka waktu izin lokasi perolehan tanah belum selesai maka izin lokasi dapat diperpanjang selama 1 tahun apabila tanah yang sudah diperoleh mencapai $50 \%$ atau lebih dari luas tanah yang ditunjuk dalam izin lokasi.

3) Keputusan Menteri Kehutanan Nomor : 79/KptsII/2001 tentang Penunjukan Kawasan Hutan dan
Perairan di Wilayah Provinsi Kalimantan Timur, dalam Amat Keempat dinyatakan Areal yang letaknya berada di luar kawasan hutan sebagaimana yang telah ditunjuk atau ditetapkan oleh Menteri Kehutanan sebelum keputusan ini, sepanjang masih dibebani Izin Usaha Pemanfaatan atau Izin Penggunaan Kawasan atau Izin Pengusahaan Pariwisata Alam, tetap menjadi Kewenangan Menteri Kehutanan sampai hak bersangkutan habis masa berlakunya.

4) Peraturan Menteri Pertanian Nomor : 98/Permentan/OT.140/9/2013 tentang Pedoman Perizinan Usaha Perkebunan, pada Pasal 21 dijelaskan untuk memperoleh Izin Usaha Perkebunan, pemohon harus melengkapi persyaratan yang salah satunya adalah Izin Lokasi Perkebunan dari Bupati/Walikota.

Izin Usaha Perkebunan (IUP) merupakan izin bagi perusahaan untuk melakukan usaha budidaya perkebunan di areal yang telah ditunjuk dalam izn lokasi dan terintegrasi dengan usaha industri pengolahan hasil perkebunan.

Dengan demikian luas IUP tidak boleh lebih besar dan tidak boleh berada di luar dari izin lokasi

5) Peraturan Menteri Agraria dan Tata Ruang/Kepala Nomor 7 Tahun 2017 tentang Pengaturan dan Tata Cara Penetapan Hak Guna Usaha, Pasal 4 dinyatakan bahwa badan hukum yang mengajukan HGU harus mempunyai Izin Lokasi sebagai dasar perolehan dan penguasaan tanah yang dimohon. Dengan kata lain permohonan HGU harus berada didalam Izin Lokasi. Selain itu izin lokasi sebagai dasar permohonan HGU harus masih berlaku sesuai peraturan perundangan yang berlaku.

6) Peraturan Daerah Kabupaten Paser Nomor 9 Tahun 2015 tentang Rencana Tata Ruang Wilayah Kabupaten Paser Tahun 2015-2035, pada Ketentuan Peralihan Pasal 102 dinyatakan bahwa izin pemanfaatan ruang yang telah dikeluarkan tetapi tidak sesuai dengan ketentuan Perda RTRW Kabupaten Paser untuk yang sudah dilaksanakan pembangunannya, pemanfaatan ruang dilakukan sampai izin terkait habis masa berlakunya dan dilakukan penyesuaian dengan fungsi Kawasan berdasarkan Perda RTRWK.

Berdasarkan peraturan perundangan tersebut di atas dibandingkan permasalahan lahan perkebunan yang ada dan dengan memperhatikan kewenangan yang dimiliki oleh Dinas PU dan Tata Ruang maka untuk validasi IGT perkebunan ditentukan aturan/rule sebagai berikut :

1) Terhadap izin lokasi perkebunan yang telah berakhir, tidak ada IUP, tidak kegiatan di lapangan dan belum ada proses HGU (kadastral) maka data spasial dihapus dari database. 
2) Terhadap Izin Lokasi perkebunan yang telah berakhir, tidak ada perpanjangan, ada kegiatan perkebunan di lapangan tapi tidak ada IUP maka perlu dicek apakah masih dalam bentuk perusahaan atau beralih ke STDP (perorangan)/plasma. Jika masih berbadan hukum maka dicabut dan dihapus dari database, sedangkan jika kebun plasma/STDP perusahaan berbadan hukum dihapus dari database menjadi kebun perorangan.

3) Terhadap overlap Izin Lokasi dengan perusahaan yang sama, luas berbeda maka izin lokasi mengacu pada SK Izin Lokasi terakhir dan jika telah ada IUP, Izin Lokasi mengacu pada perusahaan yang telah mempunyai IUP terakhir, sebagaimana contoh kasus pada Gambar 5.

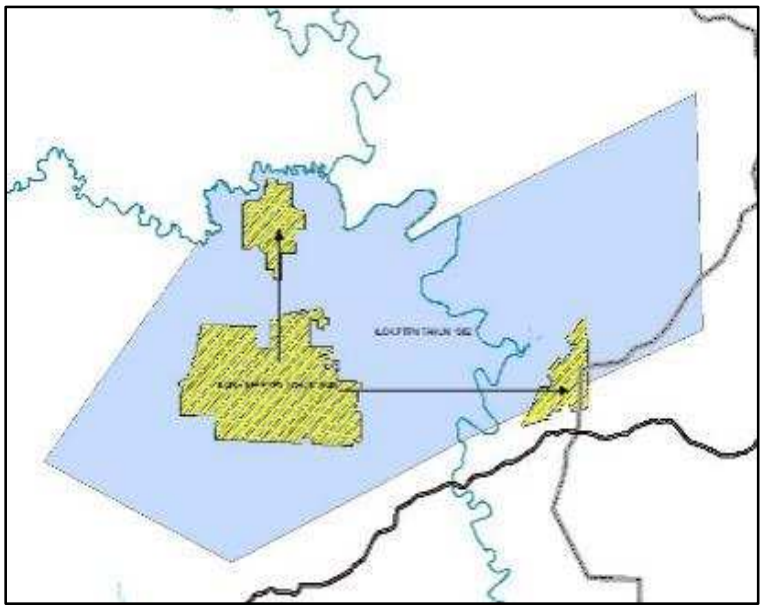

Gambar 5. Contoh kasus overlap sesama llok

4) Terhadap lokasi perkebunan yang overlap karena error dalam digitasi maka akan diperbaiki, sebagaimana terlihat pada Gambar 6. Sedangkan jika overlap cukup signifikan maka tidak dilakukan perbaikan karena berdasarkan hasil tumpang susun (overlay) dari masing-masing peta lampiran SK Izin memang terjadi overlap dan menjadi catatan untuk dilakukan revisi oleh pejabat yang berwenang, seperti ditampilkan dalam Gambar 7.

5) Terhadap Izin Lokasi dan IUP berada dalam kawasan hutan diajukan revisi ke pejabat yang berwenang untuk mengeluarkan kawasan hutan dari Izin Lokasi/IUP.

Pada Gambar 8 ditunjukan lokasi yang di arsir berada dalam Hutan Produksi (warna kuning) yang diajukan revisi Izin Lokasi/IUP

6) Terhadap Izin Lokasi dan/atau IUP berada di luar kawasan hutan namun tidak sesuai peruntukan perkebunan pada pola ruang RTRW maka jika Izin Lokasi dan/atau IUP diterbitkan setelah adanya Perda RTRW maka diajukan pembatalan Izin Lokasi dan/atau IUP kepada pejabat yang berwenang, sedangkan jika Izin Lokasi/IUP diterbitkan sebelum adanya Perda RTRW maka tidak dilakukan perbaikan sampai masa berlaku Izin Lokasi/IUP habis kecuali jika Pemerintah Daerah mampu memberikan penggantian yang layak terhadap kerugian yang diterima pemegang izin

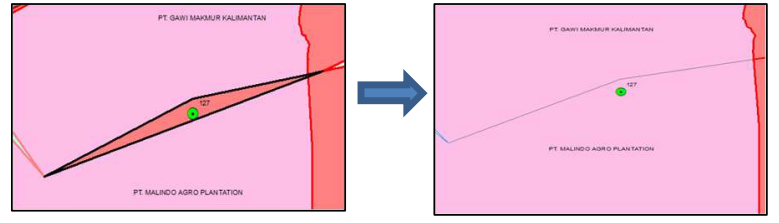

Gambar 6. Contoh kasus perbaikan overlap llok

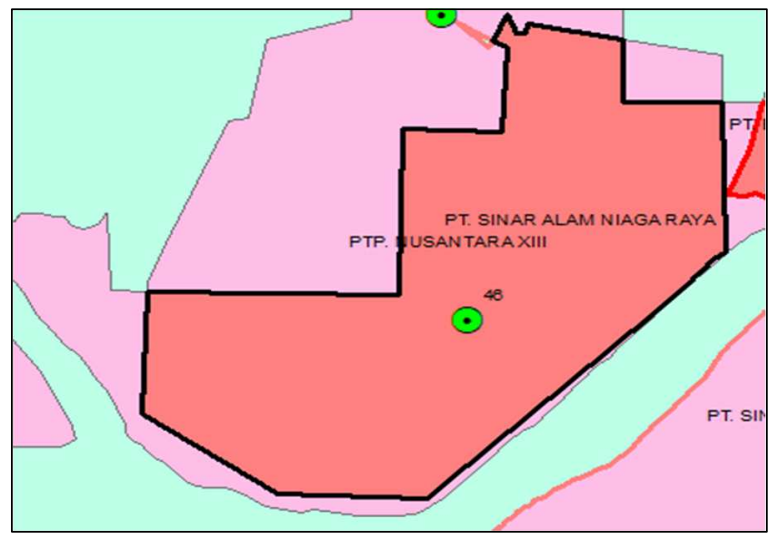

Gambar 7. Contoh kasus overlap yang diajukan revisi

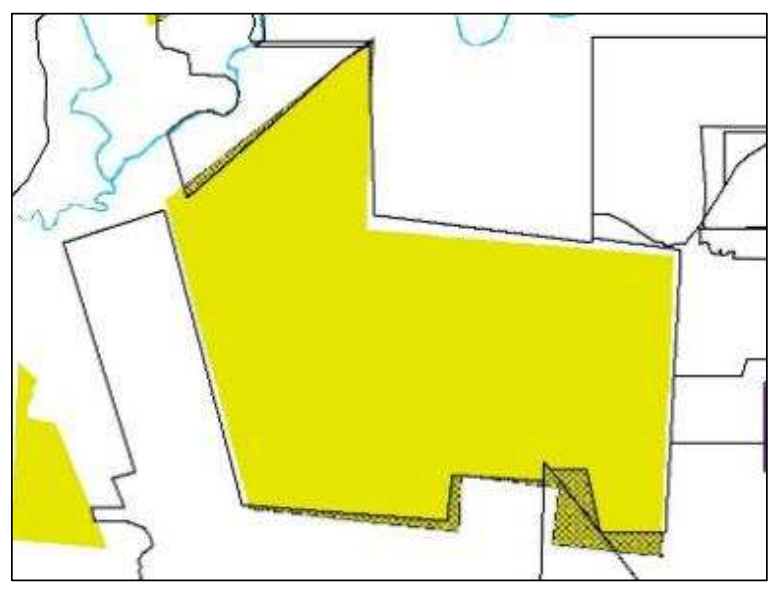

Gambar 8. Contoh kasus Ilok/IUP berada dalam kawasan hutan yang diajukan revisi

Lokasi/IUP maka izin yang sudah diberikan tersebut dapat dibatalkan.

Gambar 9 merupakan contoh kasus izin lokasi yang diberikan kepada perusahaan perkebunan kelapa sawit dimana berdasarkan Pola Ruang RTRW Kabupaten Paser berada pada Kawasan Resapan Air, namun izin dimaksud diberikan sebelum terbitnya Perda RTRW Kabupaten Paser

7) Terhadap Izin Lokasi/IUP masih dibebani Izin Usaha Pemanfaatan Hasil Hutan Kayu (IUPHHK) maka izin tetap terdata dalam database/meta data namun tidak diperkenankan melakukan kegiatan operasional lapangan sebelum areal IUPHHK di addendum oleh kementerian yang berwenang.

Pada Gambar 10 diperlihatkan contoh kasus pemberian izin lokasi perkebunan/IUP (lokasi arsir) yang masih dibebani Izin UPHHK. 


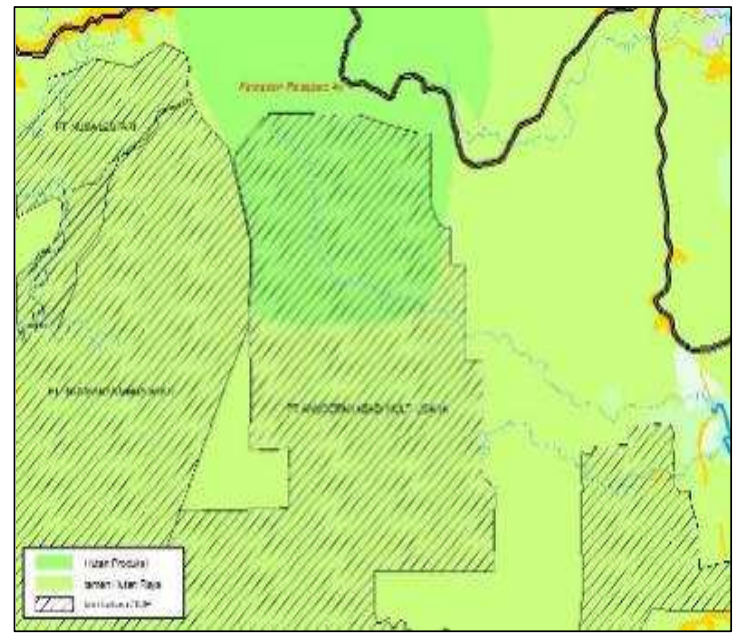

Gambar 9. Contoh kasus Ilok/IUP berada dalam Kawasan Resapan Air

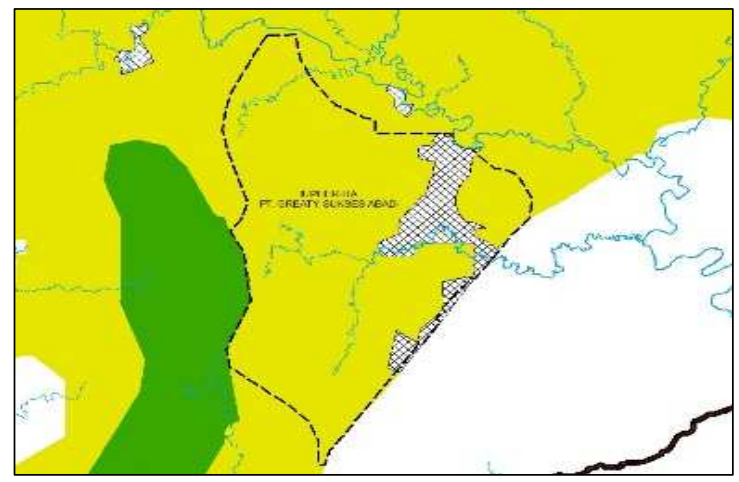

Gambar 10. Contoh kasus Ilok/IUP berada dalam Izin Usaha Pemanfaatan Hasil Hutan

8) Terhadap overlap IUP dengan IUP perusahaan lainnya maka diajukan revisi kepada pejabat yang berwenang dengan mempertimbangkan tanggal terbitnya izin dan perolehan lahan sedangkan jika overlap IUP tersebut dengan HGU perusahaan lain maka HGU dipertahankan dan IUP diajukan untuk revisi perubahan. Pada Gambar 11 diperlihatkan contoh kasus overlap IUP PTPN XIII dengan IUP PT. Pucuk Jaya, dimana PT. Pucuk Jaya telah memperoleh HGU dari BPN.

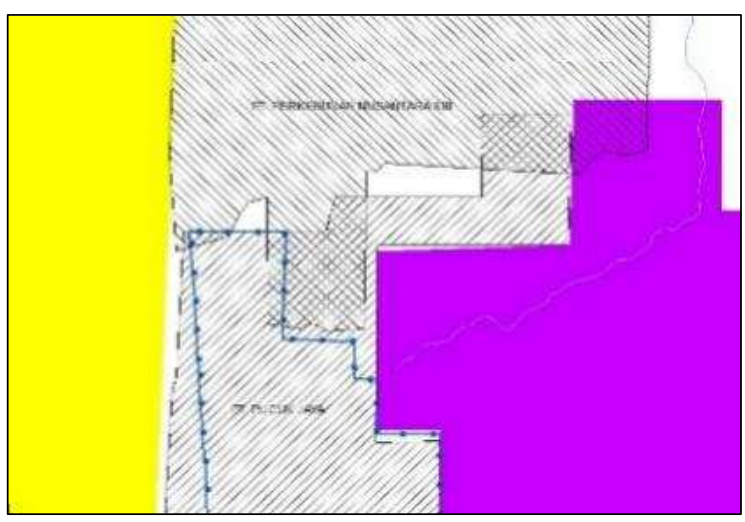

Gambar 11. Contoh kasus overlap IUP
9) Terhadap lokasi IUP yang berada diluar izin lokasinya sendiri maka SK IUP diajukan revisi sesuai Izin Lokasi atau sesuai hasil perolehan lahan dalam areal Izin Lokasi atau sesuai batas HGU.

Gambar 12 merupakan contoh kasus dimana IUP (lokasi arsir) yang sebelumnya sudah sesuai Izin Lokasi, di addendum menjadi keluar dari Izin Lokasi yang ditunjuk dan keluar dari batas HGU.

10) Terhadap pergeseran hasil pengukuran kadastral dengan IUP, jika hasil pengukuran kadastral dan IUP masih berada dalam areal yang ditunjuk Izin Lokasi maka IUP diajukan revisi dengan mengikuti hasil kadastral sedangkan jika salah satu IUP ataupun kadastral berada di luar Izin Lokasi maka perlu dilakukan klarifikasi ke instansi yang berwenang untuk mengetahui kepastian dan koordinat lokasi.

Pada Gambar 13 merupakan contoh kasus pergeseran lokasi PTPN antara hasil pengukuran bidang tanah dengan IUP

Terhadap SK IUP yang telah dicabut maka dihapus dari database/metadata

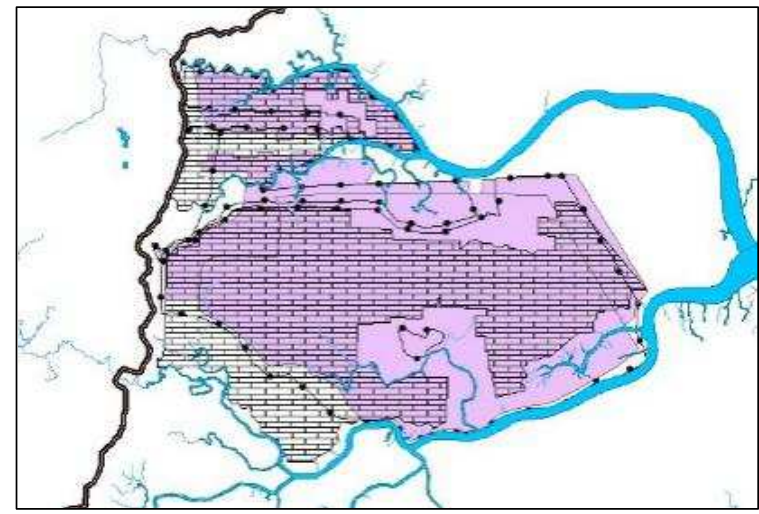

Gambar 12. Contoh kasus IUP berada diluar Izin Lokasi

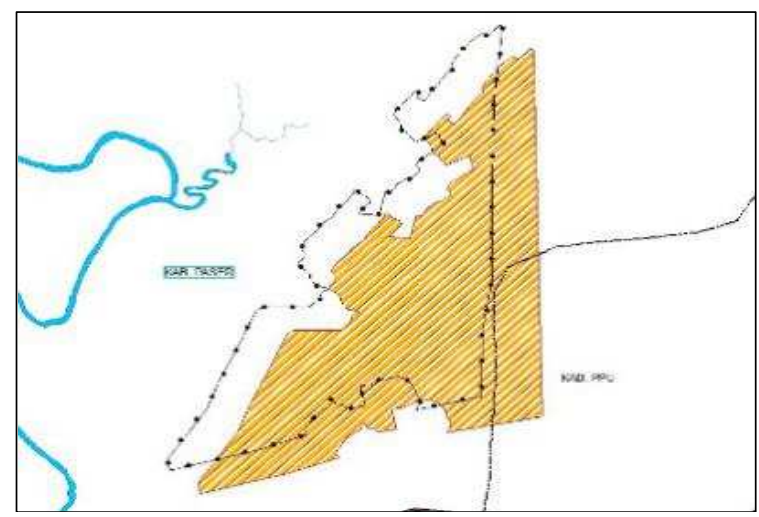

Gambar 13. Contoh kasus pergeseran kadastral dan IUP

11) Terhadap ketiadaaan lampiran peta IUP dimana luas dalam SK IUP dan SK Izin Lokasi berbeda maka data spasial IUP tetap mengacu pada peta lampiran SK Izin Lokasi dan diajukan perubahan kepada pejabat yang berwenang memperbaharui SK IUP yang dilampiri peta. 
12) Terhadap lokasi perkebunan yang masih ada gap akan diricek kembali dengan lampiran peta izin, apabila gap tersebut karena tingkat error dalam digitasi maka akan diperbaiki sedangkan apabila gap yang terjadi cukup signifikan dan telah sesuai dengan peta lampiran SK pemberian izin maka gap tersebut akan dibiarkan apa adanya dan menjadi catatan untuk dilakukan revisi oleh pejabat yang berwenang, seperti terlihat pada Gambar 14.

13) Terhadap adanya lokasi izin perkebunan yang berada di luar batas administrasi Kabupaten Paser tidak dilakukan perbaikan sampai adanya batas definitif yang ditetapkan oleh Kemendagri.

Pada Gambar 15 diperlihatkan contoh kasus izin perkebunan yang menurut Kemendagri berada diluar batas wilayah Kabupaten Paser, namun berdasarkan RTRWK masih berada dalam wilayah Kabupaten Paser

Terhadap batas lokasi perkebunan yang tidak sesuai dengan unsur IGD sungai dan jalan dari Badan Informasi Geospasial (BIG) akan diperbaiki seperlunya sepanjang lokasi perkebunan tersebut belum ada HGU. Sedangkan untuk Izin Usaha Perkebunan yang telah mengacu pada HGU tidak dilakukan perbaikan karena telah dilakukan penataan batas definitif oleh BPN yang dituangkan dalam Peta Bidang Tanah, sebagaimana terlihat dalam Gambar 16.

Berdasarkan hasil analisa spasial terhadap seluruh perizinan perkebunan di Kabupaten Paser dengan menggabungkan izin lokasi dan izin usaha perkebunan yang masih berlaku serta mempertimbangkan Hak Guna Usaha yang dimiliki perusahaan, diketahui bahwa areal perkebunan di Kabupaten Paser dari batas terluar izin adalah seluas \pm

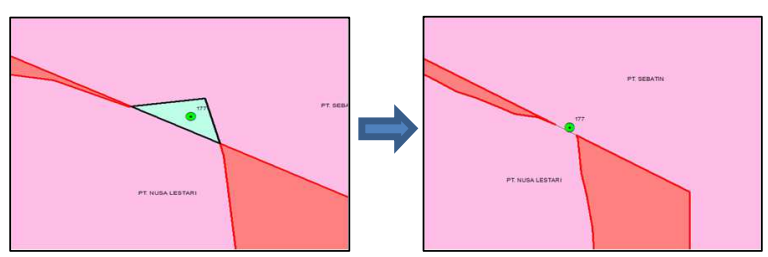

Gambar 14. Contoh kasus perbaikan gaps

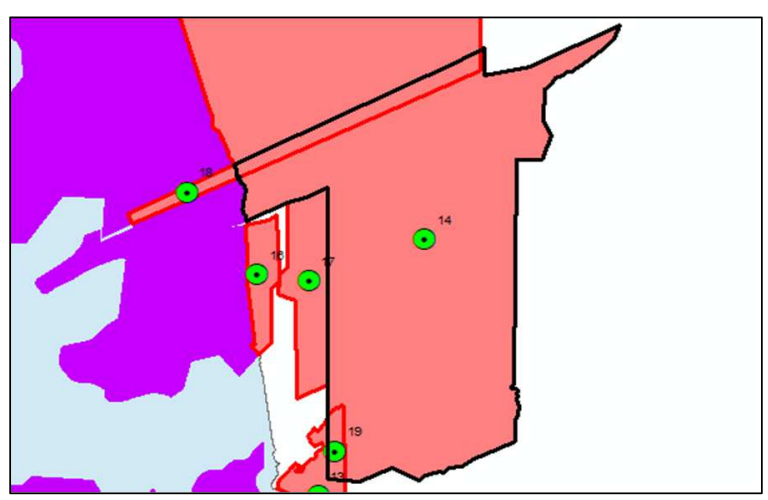

Gambar 15. Contoh kasus fitur pada batas administrasi kabupaten yang belum definitif

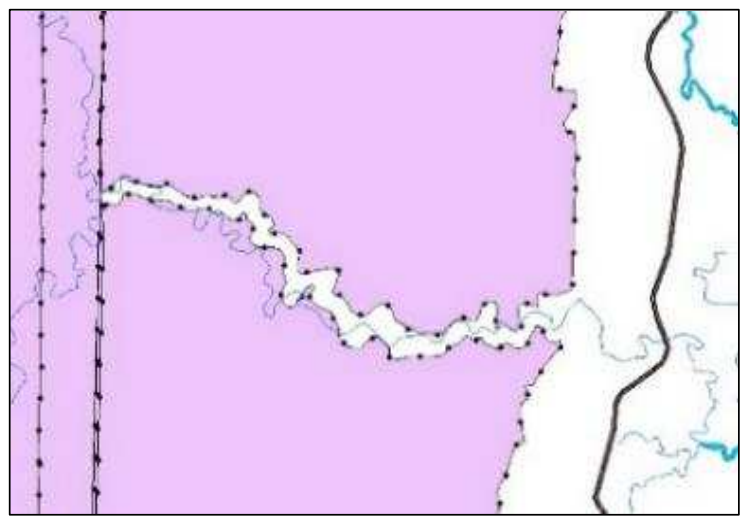

Gambar 16. Contoh kasus unsur sungai IGD tidak ssesuai batas HGU

$230.162 \mathrm{Ha}$ dari pengusaan lahan perkebunan sebelum validasi seluas $\pm 409.506 \mathrm{Ha}(56,20 \%)$, sebagaimana diperlihatkan dalam Gambar 17.

Terhadap areal perkebunan yang masih terjadi overlaping menjadi catatan untuk menjadi prioritas penyelesaian melalui revisi izin yang diterbitkan oleh pejabat yang berwenang.

Dari luas areal yang belum dibebani izin perkebunan selanjutnya akan di analisa kembali kesesuaian lahannya dengan memperhatikan daya dukung dan daya tampung lahan sebagai dasar pertimbangan Rencana Pola Ruang dalam proses Peninjauan Kembali RTRW Kabupaten Paser.

\section{Kesimpulan}

Berdasarkan hasil analisis spasial maka dapat disimpulkan hal-hal sebagai berikut :

1) Sebagian besar perusahaan perkebunan di Kabupaten Paser bermasalah dengan batas lahan

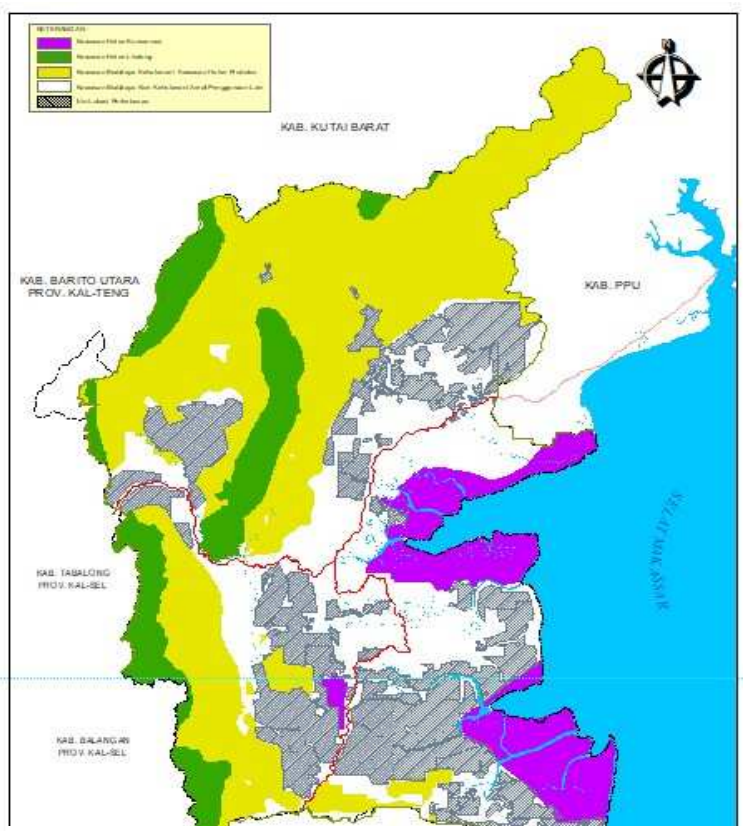

Gambar 17. Hasil Validasi Perizinan Perkebunan di Kabupaten Paser 
perkebunannya terutama tumpang tindih dengan izin perkebunan lainnya.

2) Dari hasil validasi, luas areal perkebunan di Kabupaten Paser dari batas terluar izin adalah \pm $230.162 \mathrm{Ha}$ dari pengusaan lahan perkebunan sebelum validasi seluas $\pm 409.506 \mathrm{Ha}(56,20 \%)$. Luasan tersebut belum termasuk areal overlapping yang akan ditindaklanjuti kemudian oleh pejabat yang berwenang.

\section{Ucapan Terimakasih}

Ucapan terima kasih yang sebesar-besarnya kepada Bapak Kepala Dinas Pekerjaan Umum dan Tata Ruang Kabupaten Paser yang telah mendukung kegiatan Validasi Data Lokasi Perkebunan untuk pemenuhan One Map One Data dari Stranas PK-KPK serta rekan kerja Bidang Tata Ruang yang telah membantu dalam menganalisa data spasial seluruh perizinan perkebunan di Kabupaten Paser.

\section{Referensi}

Badan Pusat Statistik Kabupaten Paser (2019). Kabupaten Paser Dalam Angka 2019. BPS Kabupaten Paser. Tana Paser

Balai Diklat Kehutanan. 2011. Materi Pelatihan Sistem Informasi Geografis ArcGIS. Samarinda.

Cholid, Sofyan (2009). Sistem Informasi Geografis: Suatu Pengantar. Bogor: Staff Akademik Departemen IImu Kesejahteraan Sosial FISIP UI. 5.

Definisi Para Ahli (2016). diunduh dari http://www.definisimenurutparaahli .com/pengertian-kompilasi/ diakses pada 29 Mei 2020

https://iam-ismail.blogspot.com/2011/09/konsepanalisis-spasial-untuk.html

Kementerian Hukum dan Hak Asasi Manusia Republik Indonesia (2001). Keputusan Menteri Kehutanan Nomor : 79/Kpts-II/2001 tentang Penunjukan Kawasan Hutan dan Perairan di Wilayah Provinsi Kalimantan Timur. Sekretariat Negara. Jakarta
Kementerian Hukum dan Hak Asasi Manusia Republik Indonesia (2011). Undang-Undang Republik Indonesia Nomor 4 Tahun 2011 tentang Informasi Geospasial. Sekretariat Negara. Jakarta.

Kementerian Hukum dan Hak Asasi Manusia Republik Indonesia (2013). Peraturan Menteri Pertanian Nomor : 98/Permentan/OT.140/9/2013 tentang Pedoman Perizinan Usaha Perkebunan. Sekretariat Negara. Jakarta.

Kementerian Hukum dan Hak Asasi Manusia Republik Indonesia (2017). Peraturan Menteri Agraria dan Tata Ruang/Kepala Badan Pertanahan Nasional Nomor 7 Tahun 2017 tentang Pengaturan dan Tata Cara Penetapan Hak Guna Usaha. Sekretariat Negara. Jakarta.

Kementerian Hukum dan Hak Asasi Manusia Republik Indonesia (2018). Peraturan Menteri Agraria dan Tata Ruang/Kepala Badan Pertanahan Nasional Nomor 14 Tahun 2018 tentang Izin Lokasi. Sekretariat Negara. Jakarta.

Nurwadjedi (2016). Kebijakan Satu Peta Dalam Mendukung Pembangunan Infrastruktur Nasional. Buletin Tata Ruang \& Pertanahan. Edisi Tahun 2016. Hal 4-8.

Sudomo, O. (2015). Topology, diunduh dari http://prohamsan.com>admin>download>2_Topology. pdf. diunduh pada 29 Mei 2020

Pemerintah Kabupaten Paser (2015). Peraturan Daerah Kabupaten Paser Nomor 9 Tahun 2015 tentang Rencana Tata Ruang Wilayah Kabupaten Paser Tahun 2015 - 2035. Sekretariat Daerah. Tana Paser.

Prasetyo, Sofyan Hadi. 2014. GIS dan Remote Sensing, diunduh dari http://gisdanrs.blogspot.com/2014/11/ gis-digitasi.html Diakses pada 29 Mei 2020

Pusat Infrastruktur Data Spasial ITB (2017). Analisis Spasial. diunduh dari https://www.slideshare.net/11-120-1/analisis-spasial-73557079 diunduh pada 29 Mei 2020

Sariwang (2016). Metode Dalam Pengumpulan Data Dalam Penelitian, diunduh dari https://sariawang.wordpress.com/2016/11/06/ metode-pengumpulan-data-dalam-penelitian/ diunduh pada 29 Mei 2020 